\title{
ОБЗОР ДОЛОМИТИЗАЦИИ НИЖНЕПАЛЕОЗОЙСКИХ КАРБОНАТНЫХ ПОРОД ЭСТОНИИ
}

В ведение. В геологической литературе по древнему палеозою Эстонии часто затрагивалась тема доломитов, в частности, высказывались суждения об их происхождении, однако систематического изложения этого вопроса пока нет. В Управлении геологии СМ ЭССР собран и систематизирован обширный материал по доломитизации нижнепалеозойских карбонатных пород Әстонии. Таких материалов, выполненных на протяжении более чем 30 лет для разных целей и с разной степенью точности и достоверности, накопилось очень много (данные почти о 8000 скважин), а поэтому единственно реальным подходом к ним было составление обзора по макроскопическим описаниям кернов скважин и карьеров.

По имеющимся макроописаниям оказалось возможным распределить породы по степени доломитизированности на 4 группы: известняки, слабои сильнодоломитизированные известняки и доломиты. Такие градации наносились на погоризонтные схемы $\left(\mathrm{B}_{\mathrm{II}}-\mathrm{J}_{2}\right)$. На основании последних составлялись карты распространения доломитов, которые выявили некоторые закономерности, заслуживающие внимания.

С тр атигр афически й обз ор. Осадочные карбонатные породы фанерозоя на территории Эстонии впервые образовались в раннем ордовике, в волховское время, и накапливались практически беспрерывно в течение всего ордовика и силура.

Горизонты нижнего ордовика - волховский $\left(\mathrm{B}_{\mathrm{II}}\right)$ и кундаский $\left(\mathrm{B}_{\mathrm{III}}\right)$, а также вышележащий азериский $\left(\mathrm{C}_{\mathrm{I}} \mathrm{a}\right)$ - характеризуются сравнительно маломощными, но литологически выдержанными и хорошо прослеживаемыми пачками (Орвику 1960 а,б). Породы волховского горизонта доломитизированы практически во всех разрезах, доступных изучению (рис. $1, a$ ). Обычно доломитизирована нижняя часть горизонта в объеме пяйтеской и сакаской пачек, суммарная мощность которых, как правило, не достигает 2 м. В них содержатся окатанные кварцевые зерна и глауконит. В шлифах иногда встречаются сохранившиеся кальцитовые частицы скелетных образований иглокожих, трилобитов, брахиопод и других беспозвоночных, а также участки теневой детритовой структуры.

В вышележащих кундаском, азериском, ласнамягиском $\left(\mathrm{C}_{\mathrm{I}} \mathrm{B}\right)$ и ухакуском $\left(\mathrm{C}_{\mathrm{I}} \mathrm{c}\right)$ горизонтах доломитовые слои менее выдержаны по сравнению с волховским и не имеют столь четких границ, но все-таки встречаются довольно часто. На рис. 1, б дана суммарная схема для таллинского надгоризонта $\left(\mathrm{C}_{\mathrm{I}}\right)$, объединяющего три горизонта, сходные по сте- 
пени и характеру доломитизации (см. также рис. 2,a). В нижней половине ласнамягиского горизонта К. Орвику (Orviku, 1940) выделил доломитовый слой, который по данным бурения нельзя считать непрерывным. Для ласнамягиского горизонта особенно характерны хорошо известные ходы илоедов, заполненные более глинистой породой и селективно доломитизированные.

Вышележащие горизонты среднего ордовика, относящиеся к карадоку, - как более чистые известняки кукрузеского $\left(\mathrm{C}_{\mathrm{II}}\right)$ и идавереского $\left(\mathrm{C}_{\mathrm{III}}\right)$, так и глинистые известняки и мергелли йыхвиского $\left(\mathrm{D}_{1}\right)$ (рис. 1,8$)$, кейлаского $\left(\mathrm{D}_{\mathrm{II}}\right)$ и оандуского $\left(\mathrm{D}_{\mathrm{III}}\right)$ горизонтов - доломитизированы очень слабо. Это относится и к рифовой фации $\mathrm{D}_{\mathrm{III}}-$ вазалеммаской пачке.

Доломитизация верхнеордовикских известняков наблюдается значительно чаще, чем нижележащих пород, и приурочена главным образом к Северной Әстонии, где преобладают чистые тонко- и скрытокристаллические известняки. В раквереском (E) и набаласком ( $\mathrm{F}_{\mathrm{Ia}}$ ) горизонтах встречаются единичные измененные разрезы в Северо-Западной Эстонии и весьма сильно доломитизированные породы на северо-востоке республики, где эти горизонты образуют местами сплошной покров (рис. $2, б)$. Вормсиский горизонт $\left(\mathrm{F}_{\mathrm{I}} \mathrm{b}\right)$ отличается преимущественным развитием глинистых известняков и мергелей, практически недоломитизированных, за исключением небольшой площади на северо-востоке республики. Зато вышележащий пиргуский горизонт $\left(\mathrm{F}_{\mathrm{I}} \mathrm{c}\right)$ в Северной Эстонии доломитизирован довольно часто, хотя и прерывисто. Маломощный поркуниский горизонт $\left(F_{I I}\right)$, венчающий ордовикский разрез, несет следы крайней мелководности, в частности рифы, а в верхней части - примесь кварцевых зерен, вплоть до кварцевых песчаников в некоторых разрезах Северо-Восточной Эстонии (Вийдинг, Ораппыльд, 1972). Эти песчаные слои содержат доломитовый цемент и по простиранию переходят в доломиты (рис. 1,2$)$. Возможно, что юго-западнее эти доломиты имеют известняковые аналоги.

Распространенные в Центральной и Южной Эстонии силурийские породы характеризуются фациальным замещением бедных нерастворимым остатком карбонатных пород более мергелистыми в западно-югозападном направлении, в сторону бывшего открытого моря. Породы, как правило, представляют собой осадки мелководных фаций. Наиболее распространены тонкозернистые разности, среди которых часты рифы, онколиты, строматолиты, окатыши (Кальо, 1970). Силурийские известняки доломитизированы намного больше ордовикских. Только в основании лландовери, в юуруском горизонте $\left(\mathrm{G}_{\mathrm{I}-\mathrm{II}}\right)$, доломитизация умеренная и развита лишь в восточной части ареала распространения. При этом верхняя пачка чистых пентамеровых известняков доломитизирована значительно чаще, чем подстилающие глинистые известняки и мергели варболаской пачки. Райккюлаский горизонт $\left(\mathrm{G}_{3}\right)$ представлен на б̆ольшей части территории материковой Эстонии доломитами (рис. $1, \partial$ ), распространение которых к западу весьма четко уменьшается. Доломиты горизонта разнообразны, на что обратила внимание Э. Юргенсон (1959). Здесь встречаются очень тонкозернистые тонкослоистые глинистые доломиты, сходные с каармаскими, а также в разной степени пористые и кавернозные разности от мелко- до крупнокристаллических. Поскольку горизонт характеризуется болышой пестротой и невыдержанностью пачек, нельзя пока говорить о возможности прослеживания каких-либо слоев преимущественной доломитизащии. Установлено (Юргенсон, 1959, 1966) убывание интенсивности доломитизации с глубнной. Вышележащий адавереский горизонт (Н) в материковой Эстонии также сложен 
доломитами, сменяющимися к юго-западу более глинистыми и менее доломитизированными разностями.

Породы венлокского яруса распространены только в юго-западной части Эстонии и представлены двумя горизонтами. Нижний, яаниский $\left(\mathrm{J}_{1}\right)$, состоит из мощной пачки в разной степени доломитизированных мергелей в базальной части и глинистых доломитов и доломитов в верхней. Яагарахуский горизонт $\left(\mathrm{J}_{2}\right)$ практически целиком сложен доломитами (рис. $1, e)$, только на западе о. Сааремаа распространены известняки. Рифовые тела прослеживаются по всему ареалу распространения горизонта независимо от современного состава пород.

Распространение верхнесилурийских и девонских доломитов авторами не изучалось, однако для последующего изложения необходимо на них остановиться, иопользуя данные других исследователей.

В верхнем силуре доломиты преобладают в двух нижележащих горизонтах: роотсикюласком $\left(\mathrm{K}_{1}\right)$ и паадласком $\left(\mathrm{K}_{2}\right)$. Здесь распространены как тонкокристаллические тонкослоистые плотные глинистые доломиты каармаского типа, давно считающиеся первичными осадками лагуны, так и кавернозные доломиты замещения. Те и другие чередуются с нормальными морскими известняками (Кальо, 1970).

В среднем девоне более или менее значительные пачки карбонатных пород встречаются в наровском горизонте, где среди песчаников, алевролитов и глин развиты глинистые доломиты и доломитовые мергели, реже доломиты. Иногда с ними ассоциируется гипс. В верхнем девоне на крайнем юго-востоке территории Эстонии развиты пластовые доломиты (Марк, Паасикиви, 1960).

Распространение доломитизации на поверхности ни жнепалеозойских пород. В зависимости от площади распространения доломитов территорию Эстонии можно разделить на две неравные части: северную, где преобладают известняки, и центральноюжную, практически покрытую доломитами (рис. 3 ).

Северная, или известняковая зона, охватывает на западе весь о. Хийумаа (стратиграфически $\mathrm{D}_{\mathrm{II}}-\mathrm{G}_{3}$ ), сужаясь к востоку как по площади, так и по стратиграфическому объему за счет выпадания горизонтов сверху. На северо-востоке республики она охватывает только средний ордовик, а за ее пределами зона иззестняков, по-видимому, выклинивается. В этой полосе встречаются отдельные доломитизированные разрезы, особенно у границы, что затрудняет оконтуривание зон.

На большей части территории Эстонии поверхность нижнепалеозойского карбонатного комплекса представлена доломитами. На северовостоке это верхний ордовик, юго-западнее - силур. Недоломитизированные участки в этом поле встречаются редко.

Условия залегания доломитов Эстонии рассматривались и ранее (Юргенсон, 1966; Кальо, 1970). Э. Юргенсон выделила на Пандивереской возвышенности в лландоверийских породах обособленное покровообразное тело мощностью 25-50 $\mathrm{\mu}$, а также второе изолированное тело доломитов мощностью более 100 м на о. Сааремаа. Нами изучалась мощность первого сверху слоя доломитизированных пород - более или менее сплошная толша (по степени доломитизации не расчлененная) с прослоями известняков. Рассматривались только те разрезы, где доломитизация начинается не глубже 10 от поверхности карбонатных пород (рис. 4). Выясняется практически сплошной покров доломитизированных пород с преобладанием доломитов, охватывающий большую часть территории республики, за исключением северной полосы. Последняя оказывается у́же, чем построенная по выходам зона известняков (рис. 3), но с более четкими границами. Мощность покрова увеличи- 
вается в юго-западном направлении, достигая максимума в районе Рижского залива. Очевидна зависимость мощности доломитизированного слоя от возраста пород - линии равных мощностей доломитов совпадают с выходами силурийских пород. Начиная с выхода райккюлаского горизонта и южнее эта закономерность затушевывает все остальные тенденции. На выходах ордовика очевидна преобладающая приуроченность доломитизации к известной полосе тектонических нарушений северо-восточного простирания, пересекающей Эстонию от Пярнуского залива до сланцевого бассейна. Выявленная на северо-эстонском глинте тенденция к увеличению степени доломитизированности пород к востоку (Orviku, $1927,1940)$ объясняется, по нашему мнению, пересечением глинта названной выше нарушенной зоной. Тектоническим строением этого участка следует, по-видимому, объяснить и характер глинта между городами Азери и Нарва, а не особым неотектоническим режимом, как это предполагалось В. Гире (Giere, 1932).

Установленный в Северо-Западной Эстонии региональный разлом в районе Ристи-Вихтерпалу (Пуура, Мардла, 1972) определяет и зону повышенной доломитизации. Эта зона является западной ветвью поля доломитизированных пород, дугой охватывающей район преимущественного развития неизмененных известняков.

Что касается литологического контроля, то практически все относительно более глинистые (и менее водопроницаемые) разности карбонатных пород $\left(\mathrm{D}_{\mathrm{I}}-\mathrm{D}_{\mathrm{III}}, \mathrm{F}_{\mathrm{I}} \mathrm{b}, \mathrm{G}_{\mathrm{I}}\right)$ доломитизированы менее, чем чистые известняки.

Связь доломитизации с современным рельефом поверхности карбонатных пород не установлена.

О генезисе доломи тов Эстонии. Выявление происхождения доломитов не было задачей настоящего обобщения, однако полученные данные об их распространении позволяют с иной точки зрения рассмотреть некоторые существующие по этому вопросу взгляды.

K сингенетическим доломитам (Страхов, 1956) в Эстонии обычно относились отдельные прослои в силурийских $\left(\mathrm{G}_{3}, \mathrm{~J}_{2}, \mathrm{~K}_{1}, \mathrm{~K}_{2}, \mathrm{~K}_{3}\right)$ (Кальо, 1970) и девонских горизонтах (Марк, Паасикиви, 1960). Распространение этих пород по разрезу и мощности весьма небольшое. Возможно, что к этой группе относятся и ассоциирующие с кварцевыми песчаниками доломиты, залегающие в верхней части $\mathrm{F}_{\mathrm{II}}$.

Маломощные пяйтеская и сакаская пачки в основании $\mathrm{B}_{\text {II }}$ (Орвику, 1960 б) имеют все признаки раннедиагенетического происхождения, сходного с доломитизацией современных осадков плоских прибрежных низин Персидского залива (Фридмен, Сендерс, 1970). Возможно сходное происхождение некоторых доломитов $\mathrm{B}_{\mathrm{III}}$ (утриаская пачка) и $\mathrm{C}_{\mathrm{I}} \mathrm{B}$ (средний доломитовый слой) горизонтов. Очевидно и диагенетическое происхождение «доломитовых ходов» в $\mathrm{C}_{\mathrm{I}}$. О диагенетической природе доломитов силура нет прямых доказательств ввиду недостаточной разработанности литостратиграфии этих пород. Однако косвенно, на основании значительной мелководности этих осадков, можно предположить значительное развитие таких доломитов (Кальо, 1970; Юргенсон, 1959, 1966).

Следует особо подчеркнуть приуроченность всех рассмотренных доломитов раннего происхождения («пластовых») к рубежам истории геологического развития территории. Доломиты $\mathrm{B}_{I I}$ - первые фанерозойские карбонаты района и знаменуют начальные стадии крупной аренигской трансгрессии Балтийского палеобассейна. Напротив, доломит Fii запечатлел завершение позднеордовикской регрессии. Верхнесилурийские первичные доломиты отражают конец существования балтийского бас- 


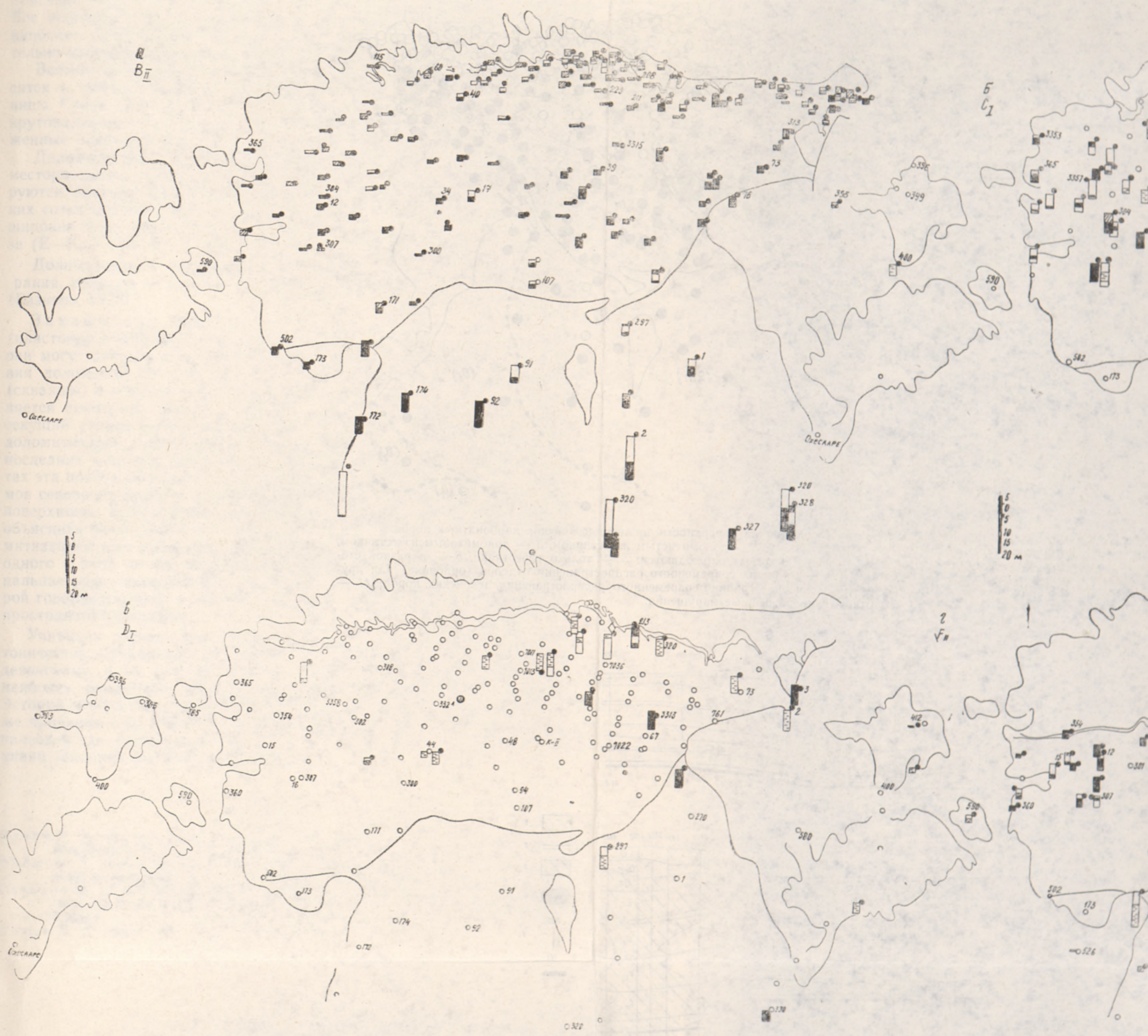

Рис. 1. Схемы распространения доломитов и известняков волховского горнзонта (a), таллинского надгоризонта (азериского +ласнамягиск
1 - контуры выходов горизонтов, 2 - северная граница современного распространения девонских пород. Карьеры: $3-$ известняков, $4-$ номер или названне), вскрывшне: 7 - только известняки, 8 - доломитизированные породы. Обозначения к колонкам, приведенным у 


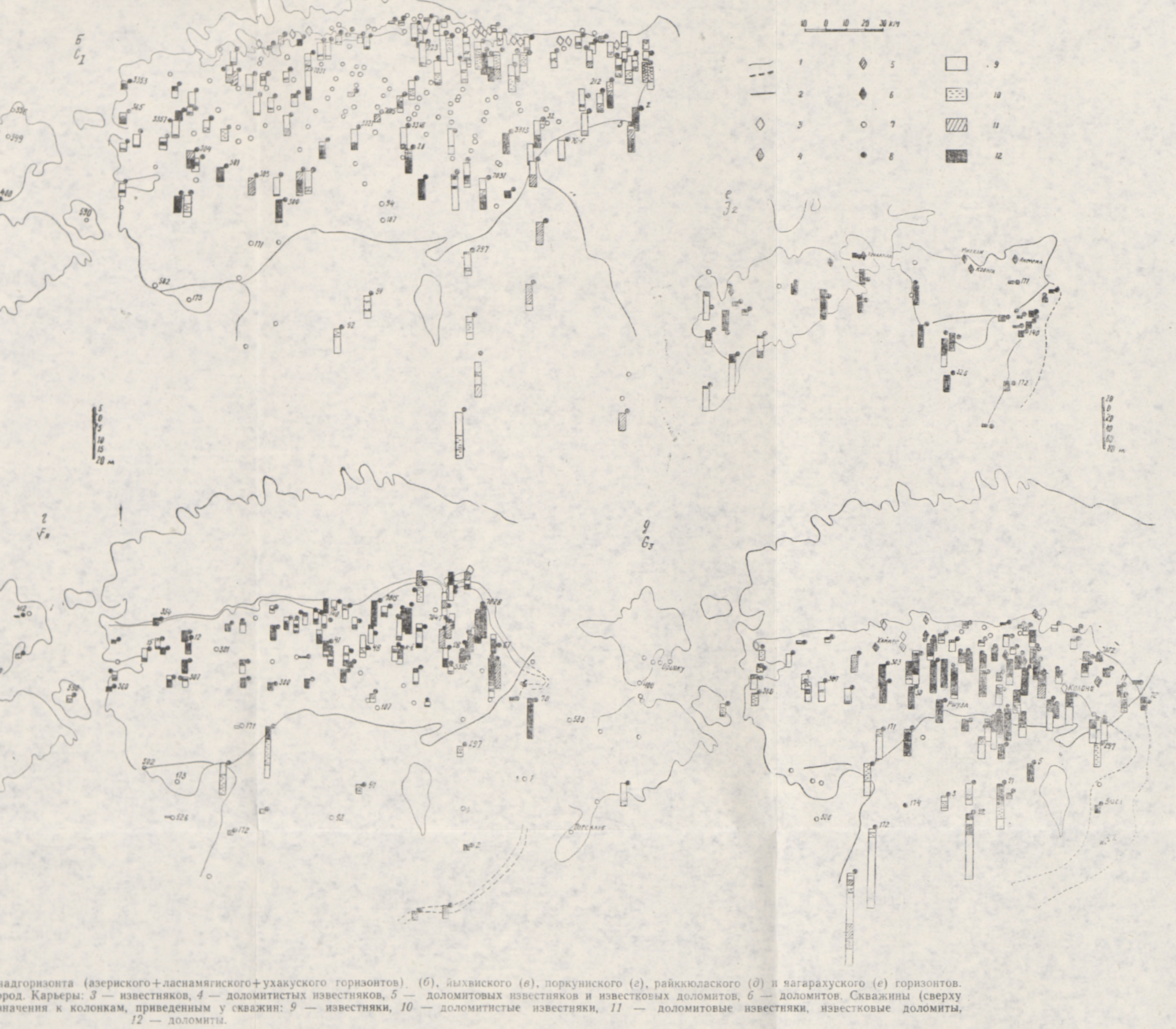




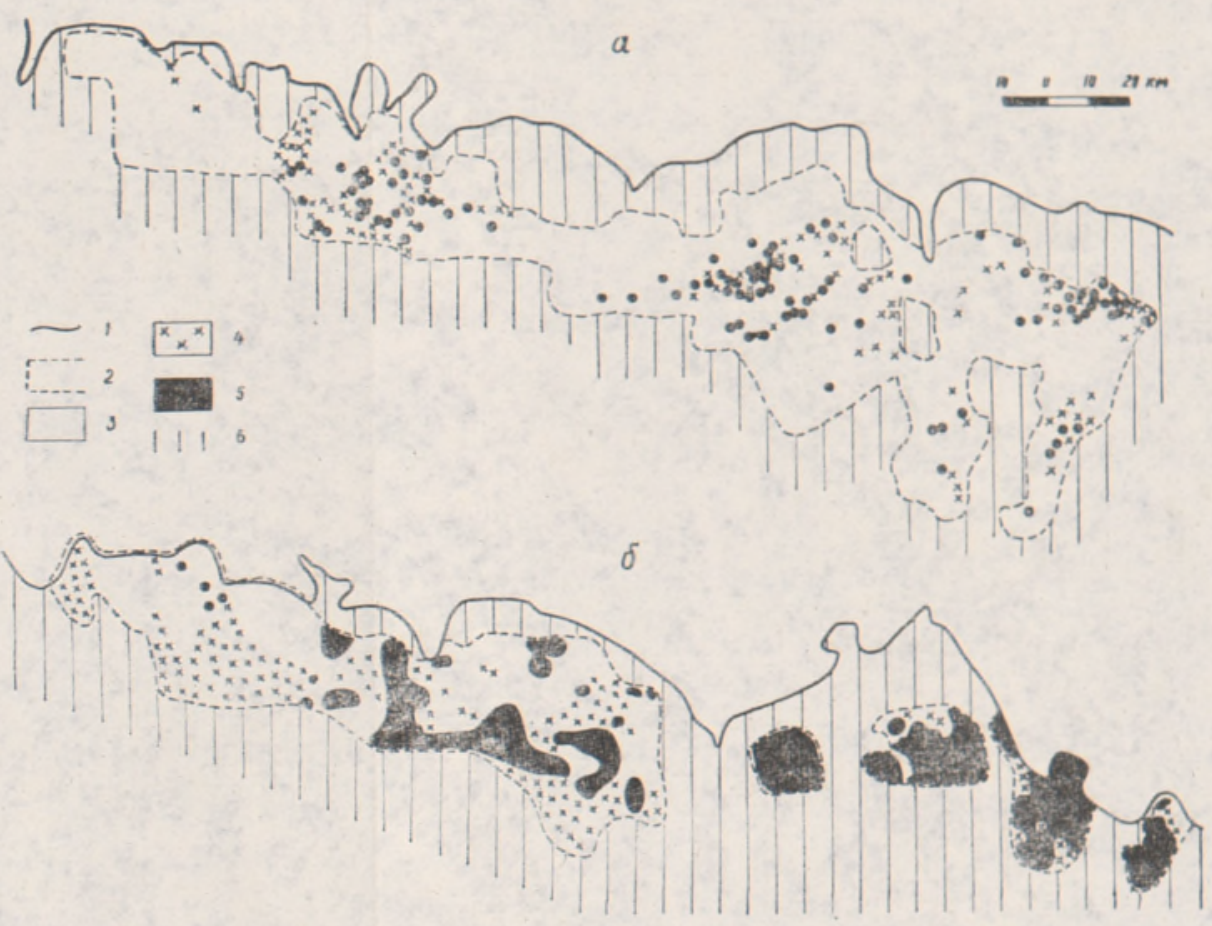

Рис. 2. Схемы распространения доломитов и известняков в ухакуском (є) и раквереском (б) горизонтах на территории Эстонского месторождения горючих сланцев. 1 - границы выходов горизонтов, 2 - контур детально разбуренных участков. Поля распространения: 3 - известняков, 4 - доломитизированных (в разной степени) известняков, 5 - доломитов (небольшой кружок обозначает одиночную скважину); 6 области, разведанные редкой сетью скважин.

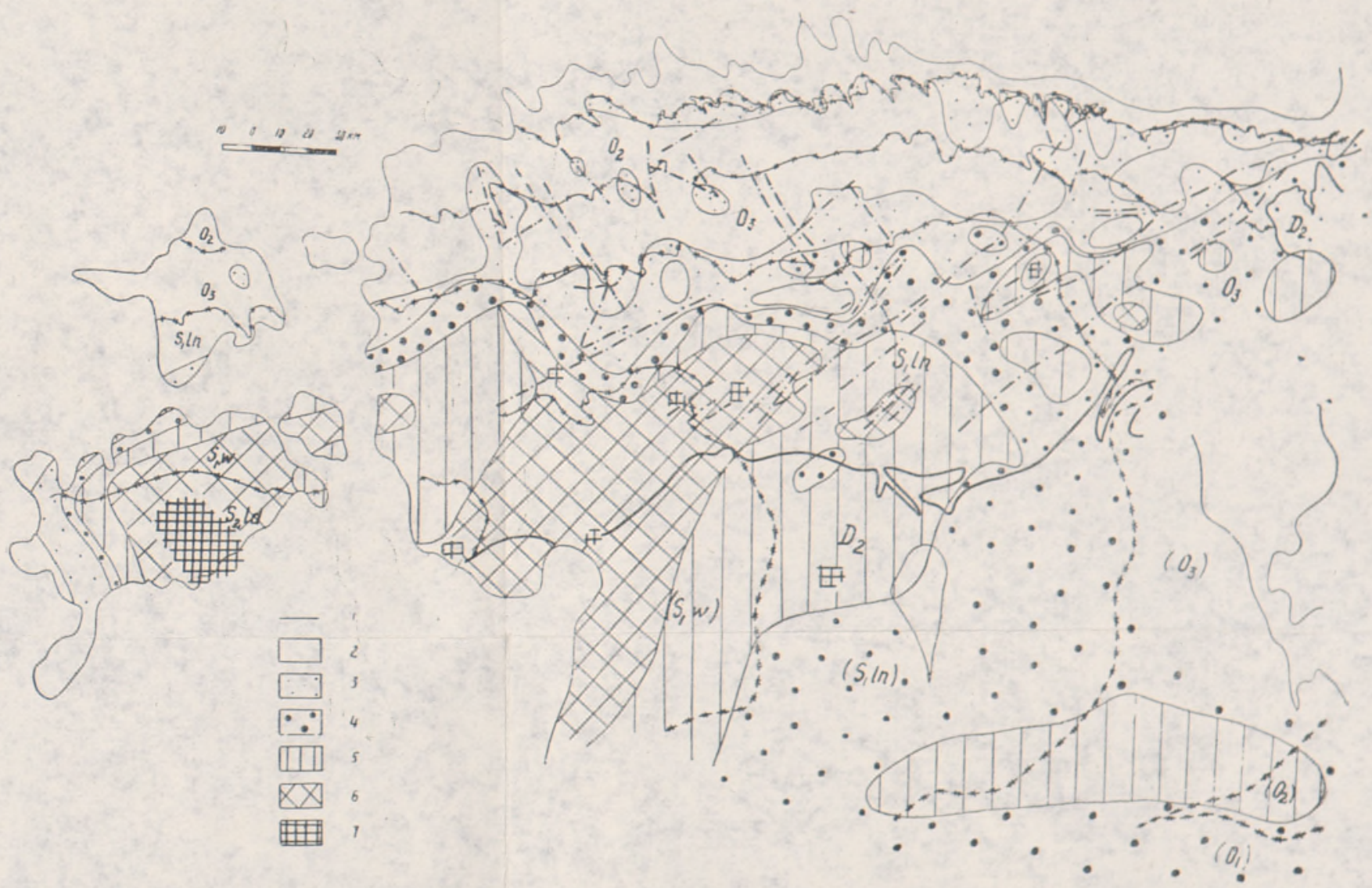

Рнс. 4. Схема мощностей первого от поверхности комплекса доломитизированных (в разной степени) пород нижнего палеозоя. - линии равных мощностей доломитизированных пород, 2 - область распространення в поверхностном слое (до глубины 10 м от поверхности) только известняков. Области распространения доломитизированных пород мощностью: $3-$ до 10 м, $4-10-$ 25 м. $5-25-50$ м, $6-50-100$ м, 7 - более 100 м. 


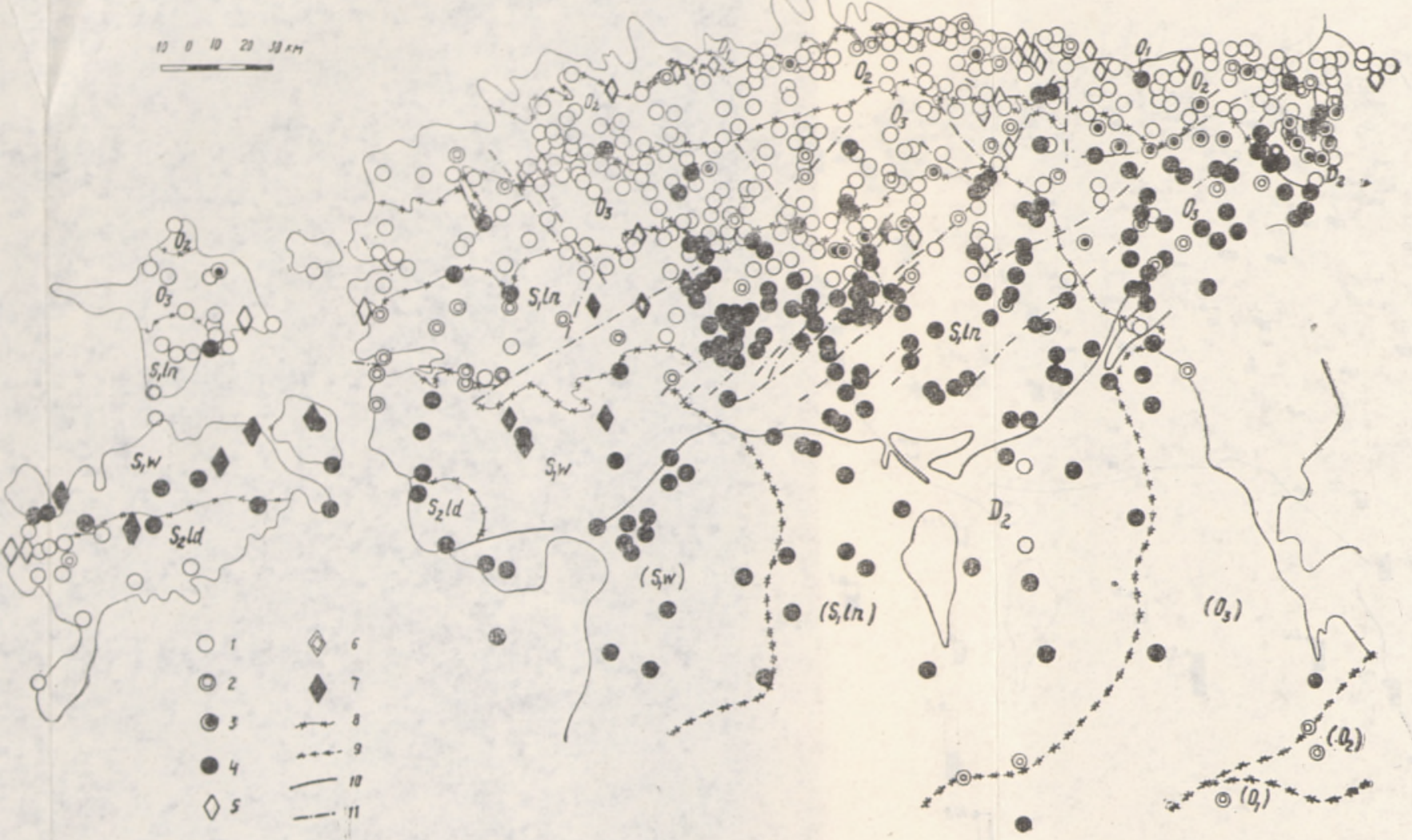

Рис. 3. Схема распространения известняков и доломитов на поверхности нижнепалеозойских карбонатных пород. Скважины, разрез которых начинается сверху: 1 - известняком, 2 - доломитистым известняком, 3 - доломитовым известняком, известковым доломитом, 4 - доломитом. Карьеры, в разрезе которых наблюдаются: 5 - только известняки, 6 - в разной степени доломитизированные известняки, 7 - доломиты; 8 - границы современного распространения отделов (ордовика) или яру сов (силура), 9 - то же под девонскими породами; 10 - северная граница современ

to
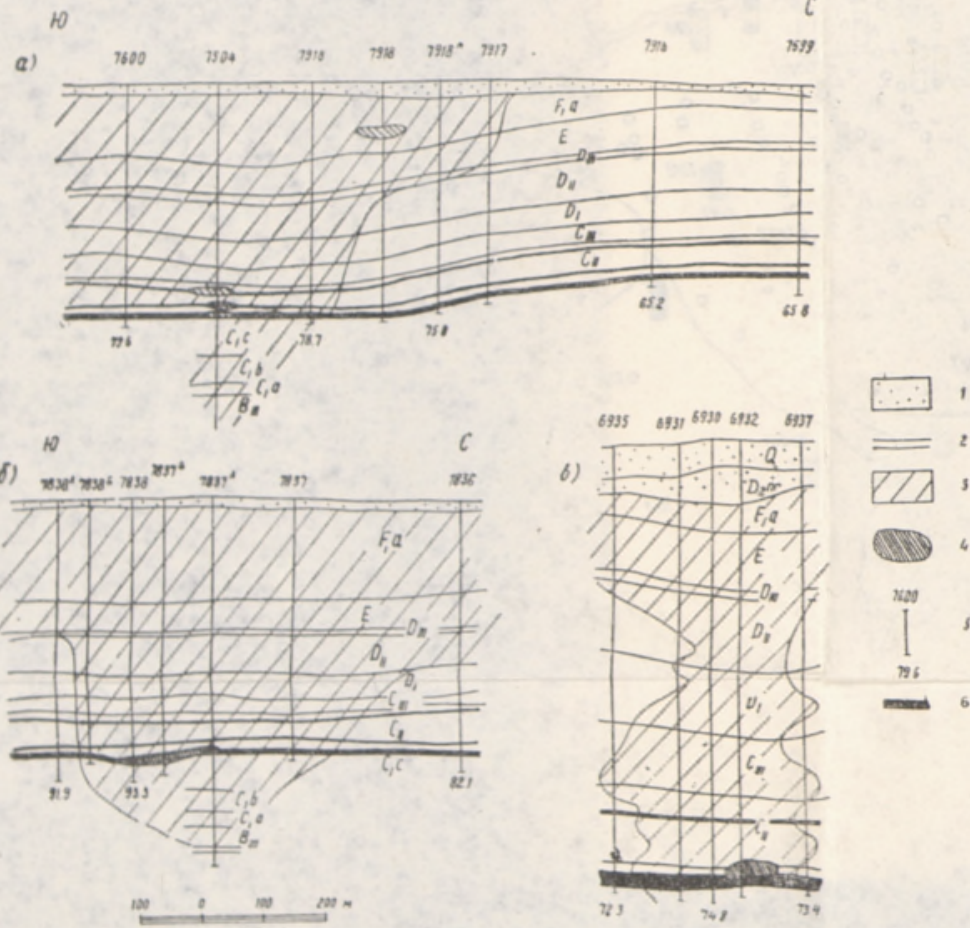

Рнс. 5. Геологнческие разрезы через зоны тектонических нарушений северо-восточного простирання на Эстонском месторожденин горючих сланщев (из отчетов А. Крапивы, О. Морозова, Э. Эрисалу и др.); $a, 6$ - Ахтмеское нарушение, в - локальное нарушение в восточной части месторождения.

1 - терригенные отложения (девонские, четвертичные), 2 границы горизонтов, 3 - зона доломитизированных пород, $4-$ карстовые зоны, 5- скважины (сверху номер, снизу глубина от устья, $\leftrightarrow), 6$ - горючий сланец. 
сейна на данной территории. Глинистые доломиты наровского горизонта отмечают начало морского осадконакопления после каледонского цикла. Все названные магнезиальные карбонаты представляют собой осадки наиболее мелководных бассейнов и отражают, по-видимому, относительно засушливые климатические периоды.

Возможно, что преобладающее большинство доломитов Эстонии относится к эпигенетическим, поскольку они секут стратиграфические границы. Среди этой группы наиболее четко выделяются вертикальные или крутопадающие тела, развитые вдоль тектонических нарушений и окруженные неизмененными известняками.

Доломитизация вдоль разломов детально изучена на эстонском месторождении горючих сланцев, где подобные тела тщательно карти руются. Ширина этих зон варьирует от нескольких десятков до нескольких сотен метров, редко до 2 км (Вахер и др., 1960), причем наиболее широкие зоны наблюдаются в верхней более проницаемой части разреза $\left(\mathrm{E}-\mathrm{F}_{\mathrm{I}} \mathrm{a}\right)$ (рис. 5). Глубина их прослеживания различна.

Доломитизация приурочена к трещинам северо-восточного простирания, которые не прослеживаются, как правило, в девонских породах (Газизов, 1972).

3 а кл ючен и е. Морфология рассмотренных выше доломитовых тел (пластовых и секущих) в общих чертах ясна и на данном уровне знаний они могут считаться частными случаями общей картины распространения доломитов Әстонии (рис. 3,4$)$. При современной густоте точек (скважин) и степени их изученности на большей части территории выделяется сплошной покров доломитов мощностью в среднем 20-30 $\mathrm{M}$, секущий стратиграфические границы. При этом наиболее интенсивная доломитизация наблюдается под девонскими отложениями и севернее последних в полосе, вероятно, покрытой ими в прошлом. В общих чертах эта полоса совпадает с отмеченной выше зоной тектонических разломов северо-восточного простирания. С другой стороны, на поддевонской поверхности встречаются и известняки. Нам кажется правдоподобным объяснить положительную связь между среднедевонским морем и доломитизацией как совпадение двух разобщенных во времени последствий одного и того же фактора. В качестве последнего предлагается региональная зона тектонических нарушений, о связи доломитизации с которой говорилось выше и которая в наровское время контролировала распространение бассейна.

Учитывая досреднедевонский возраст северо-восточной системы тектонических нарушений и перекрытие доломитизированных пород среднедевонскими, а на юго-востоке средне-нижнедевонскими отложениями, наиболее вероятным временем образования большинства доломитов Эстонии можно считать конец позднего силура - ранний девон. По тем же причинам нам кажется более вероятным, что доломитизация нижнепалеозойских известняков произошла до преобразования структурного плана основной фазой каледонского тектогенеза.

\section{Л И ТЕ Р А Т У Р А}

В ахер Р. М., Пуу ра В. А., Эриса лу Э. К. 1962. О тектоннческом строении Се веро-Восточной Эстонин. Тр. Ин-та геол. АН ЭССР, Х

В и йдин г X., О р ас п ыльд А. 1972. Литология и минералогия камарикуокой пачки поркуниского горизонта. Изв. АН ЭССР, Хим. Геол., 21, № 3.

Г а з и з в М. С. 1972. Исследование закономерностей развития карста в Прибалтийском сланцевом бассейне и его влияния на горные работы. Автореф. докт. дисс Таллин.

Кальо Д. Л. (ред.) 1970. Силур Эстонии. Таллин. 
Марк Э. Ю., Па а сикиви Л. Б. 1930. Девонская система. Геология СССР, том 28. Эстонская ССР. М.

О рви ку К. К. 1960а. Литофациальные особенности ордовикских горизонтов волхов $\left(\mathrm{B}_{11}\right)$, кунда $\left(\mathrm{B}_{111}\right)$ и азери $\left(\mathrm{C}_{\mathrm{T}} \mathrm{a}\right)$ в северной части Эстонской ССР. Междунар. геол, конрссс, XXI соссия. Докл. сов. геолотов. Пробл. 7. Стратиграфия и корреляция ордовика и силура. Л.

О рв ику К. К. 1960б. О литостратиграфии волховского и кундаского горизонтов в Эстония. Тр. Ин-та геол. АН ЭССР, V.

Пу ур а В., М ардл а А. 1972. Структурне расчленение осадочного чехла в Эстонии. Изв. АН ЭССР, Хим. Геол., 21, № 1.

С трах ов Н. М. 1956. О тнпах и генезисе доломитовых пород. В кн.: Типы доломитовых пород и их генезнс (ред. Н. М. Страхов). Тр. Геол. ин-та АН СССР, вып. 4.

Фридмен Д. М., Сендерс Д. И. 1970. Генезис и распространение доломитов. В кн.: Карбонатные породы, т. І.

Ю ргенсон Э. А. 1959, Доломиты райккюлаского горизонта нижнего силура Эстонокой ССР. Изв, АН ЭССР, Сер. техн. и физ.-матем. наук, VIII, № 3.

Юргенсон Э. А. 1066. Литология лландоверийских отложений Эстонии. Таллин.

Giere W. 1932. Morphologie der estländischen Nordküste. Königsberg, Gräfe und Unzer.

Orviku (Jaansoon) K. 1927. Beiträge zur Kenntnis der Aseri- und der Tallinna-Stufe in Eesti. I. Tartu Dlikooli Geol. Inst. Toim., nr. 5.

Orviku K. 1940. Lithologie der Tallinna Serie (Ordovizium, Estland), I. Acta et Comm. Univ. Tartuensis, A, XXXVI.

Управление геологии

Совета Министров Эстонской ССР

Поступила в редакцию

$12 / \mathrm{X} 1973$

\section{P. VINGISAAR, V. TAALMANN}

\section{OLEVAADE -EESTI VANAPALEOSOIKUMI KARBONAATSETE KIVIMITE DOLOMIIDISTUMISEST}

Eestis tehtud puuraukude südamike valdava osa provisoorsetest kirjeldustest lähtudes vaadeldakse dolomiidistumise levikut ajas ja maa-alaliselt.

Karbonatsetete moodustumine algas Eestis volhovi eal kōikjal dolomiitidega. Keskordoviitsiumi valdav osa on dolomiidistunud väga nōrgalt vôi on sellest hoopiski puutumata jäänud. Dlemordoviitsiumis aga kohtab dolomiite sageli. Siluri kivimid on ordoviitsiumiealistega vôrreldes tunduvalt enam dolomiidistunud.

Vanapaleosoikumi karbonaatsete kivimite pealispinnal esinevad enamasti dolomiidid, kusjuures ainult pōhja-loode osas on suhteliselt kitsas lubjakivide ala (joon. 3). On olemas tihe seos dolomiidistumise ja Eestit edela-kirde-suunas (Pärnu-Kohtla-Järve) läbiva tektooniliste murrangute vööndi vahel (joon. 4).

\section{P. VINGISAAR, V. TAALMANN}

\section{SURVEY OF THE DOLOMITIZATION OF THE LOWER PALAEOZOIC CARBONATE ROCKS OF ESTONIA}

On the basis of macroscopic descriptions of boring cores, the authors have attempted to systematize the distribution of dolomitization in time and space. The carbonate sedimentation on the given territory began with dolomites in the Volkhov (BII) Stage. An occurrence of rather continuous (in space) thin dolomite layers between limestones is typical of the Lower Ordovician $\left(\mathrm{B}_{\mathrm{II}}, \mathrm{B}_{\mathrm{III}}\right)$ and the lower part of the Middle Ordovician $\left(\mathrm{C}_{1}\right)$. The predominant part of the Middle Ordovician $\left(\mathrm{C}_{I I}-\mathrm{D}_{I I I}\right)$ is very slightly dolomitized, whereas in the Upper Ordovician (E-FII) dolomites are of a more frequent occurrence. The Silurian beds are more dolomitized in comparison with the Ordovician ones.

Of a rather early origin (primary, penecontemporaneous) dolomites, are mainly connected with major changes in the history of the basin - with either the beginning of transgressions or maximum regressions.

Dolomites predominate on the surface of the Lower Palaeozoic carbonate rocks, with only a rather narrow stretch of limestones occurring in the N-NW part (Fig. 3). 
The following general connexions in the dolomitization have been stated: a) with the Silurian deposits; b) with the tectonic faults zone of a NE-SW orientation (Fig. 4).

It is supposed that the major part of the dolomites are of an epigenetic origin since the complex of dolomitized rocks intersects the stratigraphic boundaries. The date of formation of the epigenetic rocks is assumed to fall in the interval of time between the Late Silurian and Early Devonian, having presumably occurred before the rearrangement of the structural pattern by the Caledonian orogenic phase. 